\title{
A teacher's tensions in a Spanish first grade two-way bilingual immersion program
}

\author{
Patricia López Estrada ${ }^{i}$ \\ Instituto Tecnológico de Costa Rica, Costa Rica
}

Ana María Chacón $n^{\mathrm{ii}}$

Barbieri Elementary Two-Way School, EUA

\begin{abstract}
This study describes a bilingual teacher's tensions in a Spanish first grade two-way immersion classroom. Drawing on Hatch's (2002) inductive analysis, in the form of domain analysis, the study data came from two teacher interviews during the 2009-2010 school year. Findings indicated that the bilingual teacher holds strong beliefs about the importance of providing students with opportunities to explore the minority language (Spanish). Yet the teacher struggles with various linguistic and academic tensions while accomplishing such task. This study calls attention to the struggles of juggling English and Spanish in the setting of two-way bilingual immersion contexts.
\end{abstract}

Keywords

Two-way immersion programs; Bilingual education; Second language learning

\section{Introduction}

A two-way immersion program (TWI) ${ }^{1}$ is "an integrated model of bilingual education where native English speakers (language majority students) and native speakers of a minority language (language minority students) are educated together for most or all of the day, and receive content and literacy instruction through both English and the minority language" (de 
Jong \& Howard, 2009, p. 81). The goals of TWI programs include academic achievement, additive bilingualism and biliteracy, and cross-cultural competence for all students (Christian, Howard, \& Loeb, 2000; García, 2004; Lessow-Hurley, 2009). These programs seek to facilitate literacy and content development in the students. The additive component aims at valuing students' native language while learning a second language. The intent is not to replace the students' native language with another language but to provide students who speak a language different from English (the majority language) the opportunity to learn English while maintaining their native language (Christian, 1994). The programs seek to place a high value on the students' language knowledge because students become the experts and the resources in the classroom (Christian, 1994).

Some characteristics of TWI programs include a balanced ratio of native and non-native speakers, an emphasis on the minority language in early grades, and students' participation in the program for at least six years (Lindholm-Leary, 2005; Thomas \& Collier, 1997). There are two main models of TWI programs. In the $90: 10$ model, students are instructed $90 \%$ of the day in the minority language and $10 \%$ of the time in English. This model takes place during kindergarten and the early years of elementary school. Then, starting in third grade, the 50:50 model is implemented, where instruction is equally divided between two languages. The language allocation can be done by content area, person, or time. The purpose of the 90:10 model, where most of the instruction is provided in the minority language, is to provide language minority students with an opportunity to learn a second language while continuing to develop their native language proficiency (Christian, 1994). The 90:10 model seeks to benefit minority students by providing an additive bilingual environment, where their native language is highly valued and their language knowledge is regarded as a classroom resource. Learning through one's native language has been proven to have many advantages, such as facilitating literacy and content knowledge not only in the native language but also in the target language (Christian, 1994; Thomas \& Collier, 1997, 2002).

\section{Challenges of TWI Programs}

TWI programs encounter many challenges in integrating native and non-native speakers, establishing equilibrium between making content 
comprehensible to non-native speakers and ensuring content is stimulating and challenging enough for the native speakers of both languages (Freeman, 1998; Hayes, 2005; Howard, Sugarman, Christian, Lindholm-Leary, \& Rodgers, 2007; Howard \& Loeb, 1998; Lindholm-Leary, 2001; Palmer, 2008a, b, 2009; Potowski, 2004; Valdés, 1997). Other challenges include understanding the role teachers play as they engage in teaching practices that seek to provide the environments necessary to foster language development and use through meaning interactions, especially in the minority language (Valdés, 1997).

Some have addressed this shortcoming of TWI programs of not providing balanced learning and instructional opportunities to develop the minority language (de Jong \& Howard, 2009; Howard, Sugarman, \& Christian, 2003; Valdés, 1997). Some potential impediments to affording equal value to the minority language include the English-dominant sociopolitical context, the value of linguistic and cultural capital, high status of English and English speakers, allocation of resources, access to quality minority language instruction, dominance of English in the school-wide environment and the larger community, access to native language models, native minority language models in peer interaction, and opportunities to model native language (de Jong \& Howard, 2009; Dubetz \& de Jong, 2011; Howard et al., 2003, Potowski, 2004). There is a tendency for students to interact in Spanish with the teacher but in English within group work and with peers. Some studies have addressed this issue of linguistic inequality where either teachers devalue Spanish (e.g. using English to announce "important" information or not allowing students to use variations of Spanish) or the entire school has a hidden curriculum that tends to value English as the language of power, the language of access, and superiority (Carrigo, 2000; Gayman, 2000; McCollum, 1994; Montague \& Meza-Zaragosa, 1999). Within the context of TWI programs, there is a growing concern about language minority maintenance, development, representation and even survival (Christian, 1994; DePalma, 2010).

Teaching advocacy in bilingual programs needs some consideration when dealing with the student population of TWI programs (Dubetz, 2014; Dubetz \& de Jong, 2011). Cohen, de la Vega, and Watson (2001) defined advocacy as "the pursuit of influencing outcomes - including public policy, resource allocation decisions within political, economic, and social systems 
and institutions - that directly affect people's lives" (p. 7). Dubetz and de Jong (2011) have addressed this term from different perspectives. They analyzed it from two main viewpoints: pedagogical and curricular choices as advocacy (with an inclusion of language choice as advocacy) and advocacy work beyond the classroom (including colleagues, family, communities, and policy makers). Within the pedagogical choices, teachers purposefully create spaces for language minority students to "participate as experts and have knowledge status" (Dubetz \& de Jong, 2001, p. 252). It is in these spaces that students can shine and excel, in terms of not only content, but students can become language experts and have some linguistic status. These choices empower teachers to have more influence in their classrooms since they might directly advocate for minority students. In that sense, teacher discourse can be a key factor of language minority advocacy since teachers can promote or diminish language status (Palmer, 2008a, b). Research has been encouraged in terms of the amount and nature of instruction in the minority language in the primary grades to learn more about effective teaching practices in TWI classrooms (Hayes, 2005; Howard et al., 2003). Less research has focused on the daily struggles teachers go through in these complex settings. This study examines a bilingual teacher's reflections about her tensions in a first grade TWI classroom.

\section{Research context}

The context for this study ${ }^{2}$ is a K-5 public, two-way Spanish immersion school in the Northeast United States. Escuela El Milagro began the TWI program model in 1990-1991. For the $2009-2010$ school year, $60 \%$ of students in the school spoke a language other than English, $49 \%$ were Limited English Proficient (LEP) students, and about 54\% qualified for free or reduced lunch (Center for Applied Linguistics, 2011). A total of 506 students enrolled in the school during the 2009-2010 school year, where the admission by ethnicity of students was $66.2 \%$ Latino, $27.1 \%$ white and $3.4 \%$ African-American. In 20092010, the school was in its third year of transitioning to an 80:20 TWI model where students were integrated during the entire instructional time and the emphasis of instruction was $80 \%$ in Spanish and $20 \%$ English. 


\section{Research participant}

Maestra Mara ${ }^{3}$ is originally from South America, where she obtained her Bachelor of Arts in Elementary Education. She worked in full immersion English programs and taught early childhood classes in her country for ten years. She obtained her Masters of Arts in Early Childhood Education in the United States in 1991 and her doctoral degree in Curriculum and Teaching in 1998. She began working at Escuela El Milagro in 2005, where she taught first, second and third grade with two TWI models: 80:20 and 90:10. She attended a dual language training during her first year teaching in Escuela El Milagro. Her bilingual education knowledge has been building up through her over 18 years of teaching experience in one-way and TWI programs.

\section{Research methods}

\section{Individual interviews}

The research participant in this study was interviewed twice. The first interview was conducted in December 2009 and the second was in June 2010. The first interview provided background about the research participant. It lasted about an hour and focused on the teacher's personal and professional background in order to establish rapport and find out more about learning and teaching experiences in terms of bilingual education and teaching in TWI programs. The second provided evidence of the teacher's set of notions about her teaching practices. This second interview was forty minutes long and was directed at talking more in depth about the participant's views of her teaching practices in terms of TWI goals, students' problem-solving skills, social and academic language, language proficiencies and students' status, and integration of native and non-native speakers in the classroom when teaching, learning, and planning curriculum.

The study used secondary data since all data for this current study belonged to a larger study in which the participant had been already selected and all data had been gathered. The extant data of the larger study sought to examine Maestra Mara's pedagogical practices during whole group Spanish instruction in a TWI first grade classroom. 


\section{A. Data analysis}

Data analysis for this study draws on Hatch's (2002) inductive analysis, specifically domain analysis (content analysis). Domain analysis is the study of semantic relationships that form categories that include other categories (Hatch, 2002). In this type of analysis, there is a constant and systematic search for patterns of meaning that are inducted from particular elements and then generated to larger categories within the data (Hatch, 2002; Spradley, 1979). It involves a constant and systematic process of identifying, summarizing and revising domains. The domains consisted of identifiable frames of analysis, creation of codes, included and cover terms and the establishment of semantic relationships. We established domains through the use of semantic relationship that link specific elements in order to create greater categories.

All data collected from interviews were transcribed. First, we identified what Hatch (2002) defines as "frames of analysis" - meaning units (p. 163) or the pieces of analyzable parts of the data. Then included terms (name of the specific elements) and cover terms were created to capture the essence of the meaningful units. We then generated the set of categories of meaning (domains) in order to establish relationships represented in the data (Hatch, 2002). At first, all domains that emerged were general since they sought to comprise all meaningful units. All the general domains were analyzed to select the domains that were salient to the study. The selection of the domains was highly related to the research purpose of the study, which was about describing the teacher's struggles and tensions when teaching in her classroom. The final step of domain analysis involved looking for themes. We examined the domains in search of repeated patterns or patterns that showed connections among the data.

We constructed a meaningful whole that represented the specific parts of the analysis by creating a summary that organized all the parts in order to create "a whole that makes sense" (Hatch, 2002, p. 175). We used inductive analysis, in the form of domain analysis, since it provided insightful information and worked effectively for extracting meaning from complex data that was gathered with an open focus in mind. This type of analysis provided a systematic approach to processing data and offered solid ways to report representative and descriptive pieces of categories. 
As part of the data analysis of the study, the teacher participant played a fundamental role. The participant was engaged in the process of constructing knowledge with the researchers and interpreting the participant's specific reality in the context of her classroom.

\section{Findings}

Through both interviews, Maestra Mara explicitly expressed some tensions she had when teaching in a TWI first grade classroom. These tensions included students' language use, promoting of problem-solving and negotiation skills, and advocating for Spanish-speaking students. It is fundamental to address and elaborate on the tensions - or struggles, as the teacher called them -, since they provided additional evidence about the beliefs that guide her teaching practices. These tensions, while presented independently, highly relate to one another.

\section{Students' language use}

Maestra Mara's tension dealt with students' use of language. More specifically, she expressed concerns about students' switching languages, mostly from Spanish to English. She believed that sometimes Englishspeaking students spoke more Spanish than the Spanish-speaking students, and that Spanish-speaking students switched from Spanish to English more frequently. She identified two main reasons for this. First, some Spanishspeaking students did not want their English-speaking peers struggling with understanding the language. Because of this, she believed that Spanish speakers were kind enough to switch to English for those students who struggled with Spanish. The second reason she proposed was that some students switched simply because their Spanish was not strong enough. She noted that switching from Spanish to English was more common when they were working in pairs or groups. When students were gathered in whole group instruction, they more consistently spoke Spanish, as she stated:

Students don't switch during whole group. In whole group they're with me. They're good. They don't switch. They know it's Spanish. It is when they are working with themselves [that they switch]. 
A constant struggle for Maestra Mara was when students worked in groups and spoke in English. She pointed out how important it was for her that students collaborated and worked in Spanish. She insisted that she created these spaces for students to interact with each other, thus using their Spanish. She believed in these spaces as unique and authentic opportunities for students to practice Spanish. Nevertheless, she also wanted students to work cooperatively, as she expressed it:

I struggle a lot if I care if they speak in Spanish or not. There are times I don't because for me it's more important they're working together.

She expressed her convictions for Spanish use, but she also indicated her support of students speaking in any language as long as they collaborated and worked together. Her main struggle becomes more evident when she argued that she did not care what language students spoke as long as they worked together, but she also communicated her belief that she had to encourage Spanish use (even when students work independently in groups), commenting:

I don't care. I don't care; but in the other hand, I'm like... because I struggle that they need Spanish right now and if I don't push them they'll never get it.

\section{Promoting of problem-solving and negotiation skills}

This tension linked to the previous one dealt with language use but related more broadly to the promotion of problem-solving and negotiation skills among the students. Maestra Mara asserted:

That's another struggle. Do I really care that they're collaborating and cooperating in English or Spanish? I don't! I just want them to cooperate, help each other, and it's fine, it's fine if it is in English. But then comes the other side of me, you know, it's like that's the tension I have all the time. It's there every day.

She believed that promoting these skills was sometimes as or more important than promoting language skills. Maestra Mara shows her frustration and uncertainty when it comes to letting students problem-solve and negotiate in the language students feel more comfortable (English), even if it is not the intended language (Spanish). She explicitly stated this was a daily struggle. 
Within this struggle, Maestra Mara also addressed a dichotomy dealing providing less structured vs. more structured classroom activities. When talking about classroom activities, Maestra Mara believed there was some tension in how she managed and balanced structured and unstructured tasks in the classroom. She believed she was an effective classroom manager who provided students with models and behavioral and managerial structures to be followed. However, she wondered if managing and controlling students was always a useful way to promote students' language and thinking skills:

There is a lot of tension for me as a teacher, like my traditional piece as a teacher, and I don't know if it's too traditional. It is that I want to control my kids and I'm good at that. I like my management piece, but for me it's also really important that when I give them the chance, when I'm not that structured, I give them the leeway of talking and problem-solving.

She commented on a specific situation in which she provided students with all possible structures and instructions to be followed. Nevertheless, within the lesson she let the students provide some ideas and insights. She reflected on the importance of having students suggest ways to deal with other aspects because students can propose viable and original ideas. She emphasized how this tension was a constant challenge in her classroom, commenting:

You know I was struggling because I wanted them to do something specific. And they came up with other ideas and so that's a clash between my traditional piece and my other pieces [language and critical thinking promoter].

Maestra Mara questioned whether giving students too many structures was counterproductive to language learning and development. She highlighted the importance of not giving many structures and providing students with opportunities to make suggestions about how to play a game, solve a problem, or decide on students' duties and tasks in their groups.

\section{Advocating for Spanish-speaking students}

Maestra Mara noted that she took Spanish-speaking students into account (more than English-speaking students) when teaching and planning. She wondered if that was appropriate when teaching both student populations. She stated that her Spanish-speaking students "have [her] heart": 
I think when I plan I think more about my Spanish speakers. When I plan, I plan to see, I have higher expectations for them than the other ones [Englishspeaking students].

When I teach, I usually think about my Spanish-speaking children. I don't know if that's correct, but that's what I do.

The primary goal for Maestra Mara was for Spanish-speaking students to excel linguistic and academically. She stated she wanted her Spanish students to shine:

Spanish speakers need more help from me than the other ones [Englishspeaking students].

It's good to be bilingual, but these [Spanish-speaking] kids really need good education because that's their future.

She compared her student populations and it was evident that she defended Spanish-speaking students. Maestra Mara believed Spanishspeaking students suffered from academic, emotional and socioeconomic disadvantages. She asserted that English-speaking students excelled, not only in academic matters but also in their linguistic skills. In this example, Maestra Mara reflected on a teacher meeting where she defended Spanishspeaking students. In the meeting, teachers within the school evaluated Spanish and English-speaking students' grades. Maestra Mara complained that Spanish-speaking students needed more reading in order for them to excel academically:

English speakers are shining and now they are bilingual. And my other babies (Spanish-speaking students), you know, I said we need to step it up. People are like: more reading for the English-speaking children; and I'm like: no more reading for my Spanish speakers! I'm like: look at the English speakers, they are shinning across the board. And where are my other babies? They have my heart. They are not here [at an excelling academic level] and that's why we need like to push them [Spanish-speaking students], but not push for the English speakers. It's for the Latinos we need to push it.

Maestra Mara believed English-speaking students did not need as much academic support as Spanish-speaking students did. She argued:

The other ones [English-speaking students] are doing it for an additive part in their lives. English-speakers are shining and now they are bilingual. 
English-speaking students became bilingual as an extra component in their academic life whereas Spanish-speaking students needed to be bilingual to keep their cultural and linguistic roots and succeed in an English-speaking country. Furthermore, she talked about some of the reasons why Englishspeaking students stood out academically, stating:

The other ones [English-speaking students] usually go beyond. They have, you know, their great background knowledge, the great parent involvement who support their reading at home. Also English-speakers have all this school language.

Maestra Mara highlighted how Spanish-speaking students did not have as many advantages. Spanish-speaking students' parents struggled in the context of the United States. Some had several jobs, lacked English skills, and had limited formal schooling knowledge. Maestra Mara was an advocate for Spanish-speaking students in her class and in the TWI school.

As one of her beliefs, she highlighted the importance of Spanish speakers speaking more Spanish because there are fewer opportunities for them to develop their language outside of school. She believes bilingual teachers need to work on language minority linguistic skills because Spanishspeaking students lack many advantages that English-speaking students have.

\section{Discussion}

Maestra Mara held strong beliefs about Spanish-speaking students being proficient in Spanish and wanted them to excel. She sought to push them and struggled when they were marginalized by other classmates in the class or even teachers in the school. Her expectations for Spanish-speaking students indicated she cared for and believed in the students. Linguistically speaking, Maestra Mara makes it evident that she aims at promoting students' meaningful use of Spanish in the class. At times, however, when the aim is promoting problem-solving and negotiation skills, she struggles to decide whether Spanish or English should matter more. Her tension indicates a struggle between the use of the two languages. This feeling of not knowing became an evident tension in her daily teaching practices. 
Banks et al. (2005) have addressed the importance of teachers' attitudes and expectations, as well as their dispositions with regard to the students they teach. Dispositions, including valuing students' linguistic and cultural strengths, result in more student participation in the classroom. Villegas and Lucas (2007) state that having high expectations for the students and approaching the students' education in responsive ways leads to engaging students in effective school learning. Martin-Beltrán (2010) suggested that teacher talk in the classroom can convey high or low expectations. Teacher talk can invite or alienate students from classroom participation. Equally important, "effective teachers create learning environments for bilingual learners that purposefully build on and extend the linguistic and cultural resources that students bring to school" (Dubetz \& de Jong, 2011, p. 255).

Maestra Mara made sure the students were provided with an environment in which they could shine both linguistic and academically. She believed in finding a balance between developing linguistic and cognitive skills in the students. She promoted language, problem-solving, and negotiation skills development. As clearly evidenced in the findings, this balance created a tension since she doubted on which aspect (linguistics or cognition) to put more emphasis on. She provided students with the spaces to develop language and collaborate together, all simultaneously. Yet, at times, she felt these interactions should go more unplanned and less structured. This notion of not planning became also a noticeable struggle in her daily instruction practices.

Language teacher educators need to address the importance of building a classroom community where Spanish-speaking and Englishspeaking students learn from one another through the use of language and through problem-solving and negotiating situations. A suggestion for teacher educators relates to culturally responsive pedagogy, which addresses the needs of students coming from culturally and linguistically diverse backgrounds. Villegas and Lucas $(2002,2007)$ proposed six salient qualities for professional development of teachers and teacher educators, including understanding how learners construct knowledge, learning about students' lives, being socioculturally conscious, holding affirming views about diversity, using appropriate strategies, and advocating for all students. Culturally 
responsive pedagogy speaks of teaching approaches in which students are given opportunities to engage in meaningful activities where they "learn to think critically, become creative problem-solvers, and develop skills for working collaboratively" (Villegas \& Lucas, 2002, p. 30). This pedagogy reinforces the fact that all students are capable learners regardless of their cultural or linguistic background and encourages teachers to hold affirming high expectations for all students.

Maestra Mara highlighted the importance of Spanish speakers speaking more Spanish because there are fewer opportunities for them to develop their language outside of school. She believes bilingual teachers need to work on language minority linguistic skills because Spanish-speaking students lack many advantages that English-speaking students have. She advocated for the Spanish students because she more fully felt identified with their realities and socio-academic situations. Maestra Mara reflected on her practices as being a Latina who advocates for her Latino students and emphasizes the fact that Spanish-speaking student population's linguistic and cognitive needs should be more effectively addressed in TWI programs.

Howard and Loeb (1998) claim that, to more accurately prepare teachers to work in TWI programs, more needs to be searched about bilingual teachers' beliefs and daily struggles. They argue that fairness and equality of opportunity should be premises in TWI programs, as well as teachers' beliefs that TWI are truthful scenarios in which native Spanish speaking students can genuinely validate their identity and shine as the masters of knowledge, as the language authorities. In order to guarantee the success of TWI programs, teachers have to believe in the program ideals, in bilingual education, and in the significance of learning other languages and cultures (Howard \& Loeb, 1998).

\section{Conclusions}

This study highlights the complexity of teaching in a TWI scenario and how a bilingual teacher juggled diverse and intricate expectations and beliefs about the teaching of culturally and linguistically diverse students in a first grade TWI classroom. TWI programs vividly reflect how unique these teaching environments are since teachers in these contexts must aim at, not only 
making content comprehensible to one student population and stimulating and challenging for the other student population, but also validating all students' linguistic and cultural backgrounds. In these contexts, both languages (minority and majority) should be equally addressed. Yet, due to the dynamics of each language within the different social constructs (outside and inside school), balancing and placing equal value of both languages becomes a challenging task. Maestra Mara illustrates how challenging it is to promote one language over the other. She addressed her various struggles when trying to accomplish such task. Her beliefs go hand and hand in terms of promoting Spanish yet when promoting other skills (problem-solving and negotiating), she seems to obviate the fact that Spanish must prevail during the class.

It seems mandatory to delve more into bilingual teachers' beliefs and advocacy pattern sets since they may hold key aspects when teaching in TWI programs. For teacher educators, it is correspondingly required to understand the pattern sets bilingual teachers hold, both from the minority and majority language. Understanding them will help in-service and pre-service teachers of bilingual education contexts to better comprehend the academic, cognitive and socio-affective needs of culturally and linguistically diverse students, which can result in effective pedagogical practices and positive educational student outcomes.

More research is needed to apprehend how TWI teachers' embedded beliefs can delimit academic disposition and empathy towards language minority students. More research is also required to understand the perceptions of teachers who share similar linguistic and cultural backgrounds with the students and the struggles and tensions in TWI programs. More specifically, understanding Latino teachers' insights, reflections, expectations and beliefs when teaching Latino students in TWI programs. Another key aspect deals with understanding more about advocacy patterns at the classroom level, in terms of language and culture choice. Conducting more research in this area is mandatory to continue expanding on effective teaching practices to better serve the linguistic and culturally diverse student population in TWI programs. 


\section{Notes}

1 Two-way immersion (TWI) will be terms used for this paper even when there are others that refer to the same programs, including two-way bilingual, dual language, bilingual immersion and double immersion (Center for Applied Linguistics, 2011).

2 We would like to thank the research participant of the study and all the support provided by the school context.

3 The teacher and school were assigned pseudonyms.

\section{References}

Banks, J., Cochran-Smith, M., Moll, L., Richert, A., Zeichner, K., LePage, P., ...McDonald, M. (2005). Teaching diverse learners. In L. Darling- Hammond \& J. Bransford (Eds.), Preparing teachers for a changing world: What teachers should learn and be able to do (pp. 232-274). California: Jossey-Bass Education Series.

Carrigo, D. L. (2000). Just how much English are they using? Teacher and student language distribution patterns, between Spanish and English, in upper-grade, two-way immersion Spanish classes (Unpublished doctoral dissertation). Harvard University, Cambridge, MA.

Center for Applied Linguistics (2011). Directory of two-way bilingual immersion programs in the U.S. Retrieved from: http://www.cal.org/twi/directory/.

Christian, D. (1994). Two-way bilingual education: Students learning through two languages. Santa Cruz, CA: The National Center for Research on Cultural Diversity and Second Language Learning.

Christian, D., Howard, E. R., \& Loeb, M. I. (2000). Bilingualism for all: Two-way immersion in the United States. Theory into Practice, 39(4), 258-266.

Cohen, D., de la Vega, R., \& Watson, G. (2001). Advocacy for social justice. Bloomfield, CT: Kumarian.

de Jong, E. J., \& Howard, E. (2009). Integration in two-way immersion education: Equalising linguistic benefits for all students. International Journal of Bilingual Education and Bilingualism, 12(1), 81-99.

DePalma, R. (2010). Language use in the two-way classroom: Lessons from a SpanishEnglish bilingual kindergarten. Bristol: Multilingual Matters.

Dubetz, N. E. (2014). Enacting advocacy-oriented visions of bilingual education. NABE Journal of Research and Practice, 5, 1-26.

Dubetz, N. E., \& de Jong, E. J. (2011). Teacher advocacy in bilingual programs. Bilingual Research Journal, 34, 248-262.

Freeman, R. D. (1998). Bilingual education and social change. Clevedon, UK: Multilingual Matters.

García, E. E. (2004). Teaching and learning in two languages. New York, NY: Teachers College Press. 
Gayman, S. M. (2000). Understanding language use and social interaction in a French/ English two-way immersion classroom (Unpublished doctoral dissertation). University of Pennsylvania, Philadelphia, PA.

Hatch, J. A. (2002). Doing qualitative research in education settings. Albany, NY: State University of New York Press.

Hayes, R. (2005). Conversation, negotiation, and the word as deed: Linguistic interaction in a dual language program. Linguistics and Education, 16, 93-112.

Howard, E. R., \& Loeb, M. I. (1998). In their own words: Two-way immersion teachers talk about their professional experiences. Washington, DC: Center for Applied Linguistics.

Howard, E. R., Sugarman, J., \& Christian, D. (2003). Trends in two-way immersion education: $A$ review of the research. Washington, DC: Center for Applied Linguistics.

Howard, E. R., Sugarman, J., Christian, D., Lindholm-Leary, K. J., \& Rodgers, D. (2007). Guiding principles for dual language education. Washington, DC: Center for Applied Linguistics/National Clearinghouse for English Language Acquisition.

Lessow-Hurley, J. (2009). The foundations of dual language instruction. San Francisco, CA: Pearson.

Lindholm-Leary, K. (2001). Dual language education. Clevedon, UK: Multilingual Matters.

Lindholm-Leary, K. J. (2005). The rich promise of two-way immersion. Educational Leadership, 62(4), 56-59.

Martin-Beltrán, M. (2010). Positioning proficiency: How students and teachers (de)construct language proficiency at school. Linguistics and Education, 21, 257-281.

McCollum, P. (1994). Language use in two-way bilingual programs. IDRA Newsletter, 21(2), 1, 9-11.

Montague, N. S., \& Meza-Zaragosa, E. (1999). Elicited response in the pre-kindergarten setting with a dual-language program: Good or bad idea? Bilingual Research Journal, 23(2-3), 289-296.

Palmer, D. (2008a). Building and destroying students' 'academic identities': The power of discourse in a two-way immersion classroom. International Journal of Qualitative Studies in Education, 21(6), 647-667.

Palmer, D. (2008b). Diversity up close: Building alternative discourses in the two-way immersion classroom. In T. W. Fortune \& D. J. Tedick (Eds.), Pathways to bilingualism: Evolving perspectives on immersion education (pp. 97-116). New York: Multilingual Matters.

Palmer, D. (2009). Code-switching and symbolic power in a second-grade two-way classroom: A teacher's motivation system gone awry. Bilingual Research Journal, 32, 42-59.

Potowski, K. (2004). Student Spanish use and investment in a dual immersion classroom: Implications for second language acquisition and heritage language maintenance. The Modern Language Journal, 88(1), 75-101. 
Spradley, J. P. (1979). The ethnographic interview. New York: Holt, Rinehart \& Winston.

Thomas, W., \& Collier, V. (1997). School effectiveness for language minority students. Washington, DC: NCBE.

Thomas, W., \& Collier, V. (2002). A national study on the school effectiveness for language minority students' long-term academic achievement. Final report: Project 1.1. Santa Cruz, CA: Center for Excellence on Education, Diversity, \& Excellence. Retrieved from http://www.crede.ucsc.edu/research/llaa/ 1.1_conclusions.html.

Valdés, G. (1997). Dual-language immersion programs: A cautionary note concerning the education of language-minority students. Harvard Educational Review, 67(3), 391-429.

Villegas, A. M., \& Lucas, T. (2002). Educating culturally responsive teachers: A coherent approach. New York: State University of New York Press.

Villegas, A. M., \& Lucas, T. (2007). The culturally responsive teacher. Educational Leadership, 64(6) 28-33. 
TENSÕES DE UMA PROFESSORA DE $1^{\circ}$ ANO DE ESPANHOL NUM PROGRAMA DE IMERSÃO BILINGUE 'TWO-WAY'

Resumo

Este estudo descreve as tensões sentidas por uma professora de $1^{\circ}$ ano numa sala de aula de imersão bilingue 'two-way'. Baseando-se na análise indutiva de Hatch (2002), sob a forma de análise de domínio (domain analysis), os dados do estudo foram obtidos através de duas entrevistas a uma professora no ano letivo de 2009-2010. Os resultados indicam que a professora bilingue detém crenças fortes acerca da importância de proporcionar aos alunos oportunidades de explorar a língua minoritária (Espanhol). Contudo, a professora manifesta preocupações de âmbito linguístico e académico no desempenho da sua tarefa. $O$ estudo alerta para as tensões inerentes a trabalhar com o Espanhol e o Inglês num contexto de imersão bilingue 'two-way'.

Palavras-chave

Programas de imersão 'two-way'; Educação bilingue; Aprendizagem de uma língua segunda

TENSIONES DE UNA MAESTRA EN UNA CLASE DE ESPAÑOL DE PRIMER GRADO EN UN PROGRAMA DE INMERSIÓN BILINGÜE DE DOBLE VÍA

\section{Resumen}

El estudio describe las tensiones de una maestra bilingüe en una clase de español de primer grado en una escuela de inmersión bilingüe de doble vía. El estudio se basa en el paradigma cualitativo inductivo (Hatch, 2002), en forma de análisis de dominio (domain analysis), donde los datos provienen de dos entrevistas de la maestra bilingüe en el período lectivo 2009-2010. Los resultados revelan que la maestra bilingüe considera la necesidad de 
promover oportunidades para la práctica del español en los estudiantes. Sin embargo, la maestra manifiesta preocupaciones en el ámbito lingüístico y académico. El estudio hace énfasis sobre las tensiones de trabajar con dos idiomas (español e inglés) en contextos de programas de inmersión bilingüe de doble vía.

Palabras-clave

Programas de immersión de doble vía; Educación bilingue; Aprendizaje de un segundo idioma

Recebido em junho/2015

Aceite para publicação em outubro/2015

i Escuela de Idiomas y Ciencias Sociales, Instituto Tecnológico de Costa Rica, Sede Regional San Carlos, Costa Rica.

ii Barbieri Elementary, Two-Way School, Framingham, Massachusetts, EUA.

Toda a correspondência relativa a este artigo deve ser enviada para: Patricia López Estrada, Instituto Tecnológico de Costa Rica, Sede Regional San Carlos, 223-21001 Ciudad Quesada, Alajuela, Costa Rica. E-mail: plopez@gmail.com 